\title{
RELATIONSHIP BETWEEN COTTON PRODUCTIVITY AND VARIABILITY OF NDVI OBTAINED BY LANDSAT IMAGES
}

\author{
RELAÇÃO ENTRE PRODUTIVIDADE DO ALGODOEIRO E VARIABILIDADE DO \\ NDVI OBTIDO POR IMAGENS DO LANDSAT
}

\author{
Fabio Henrique Rojo BAIO'; Danilo Carvalho NEVES'; Cid Naudi da Silva CAMPOS; \\ Paulo Eduardo TEODORO ${ }^{1}$ \\ 1. Universidade Federal de Mato Grosso do Sul, Campus de Chapadão do Sul, Chapadão do Sul, MS, Brasil. eduteodoro@hotmail.com
}

\begin{abstract}
The availability of satellite images has generated a large number of regional and global studies on vegetation mapping. Such studies have related the growth parameters, nutrient status, physiological responses, and water resources to the yield of agricultural crops or native vegetation. The NDVI (Normalized Difference Vegetation Index) is associated with parameters of growth and yield with readings at several moments of the crop cycle. The objective of this work was to correlate the yield and variability of the NDVI in cotton fields by analyzing Landsat satellite images acquired over nine growing seasons. The study involved the analysis of 101 cotton production fields located in West-Central Brazil. One Landsat image was used during each crop cycle, and the average yield was computed based on total fiber harvested at each field. The fiber yield ranged from 393 to $2,030 \mathrm{~kg} \mathrm{ha}^{-1,}$ and its correlation with NDVI was 0.37 . The coefficient of variation $(\mathrm{CV})$ had a negative correlation with yield, approximating $-58.1 \mathrm{~kg} \mathrm{ha}^{-1}$ for every one percent increment of the $\mathrm{CV}$. The CV explained the yield variability over the cotton fields more accurately than the average absolute NDVI value.
\end{abstract}

KEYWORDS: Coefficient of variation. Orbital image. Vegetation index.

\section{INTRODUCTION}

The use of techniques that improves farming input efficiencies can increase the yield of important agricultural crops, such as cotton, rice, maize, soy, wheat, and sorghum. The techniques of precision agriculture are essential tools for this purpose as they can maximize food production, reduce costs and minimize environmental impacts (WALSH et al., 2012). Remote sensing tools can evaluate and describe the interactions of environment variables related to plant growth (OLLINGER, 2011). These studies provide critical conservational data associated with several plant growth parameters, such as the leaf area index (LAI), biomass production, hydric condition of plants, and overall agricultural efficiencies (ZHENG; MOSKAL, 2009; WIENS et al., 2009).

A balance between vegetative and reproductive growth structures in the cotton plant is essential to achieve high yields and remains a challenge in managing the crop (Booker et al. 2015). Gutierrez et al. (2012) mentioned that cotton yield is related to the amount of leaf photosynthetic tissue, and highly correlated with leaf area index (LAI) and biomass, which are two parameters of crop growth that can be estimated by vegetation indices (YANG and EVERITT, 2012; YANG et al., 2015). The correlation between the vegetation index and yield is known in several crops. Several vegetation indices are available, but normalized difference vegetation index (NDVI) is the most widely studied. The relationship between NDVI and parameters of growth and yield of the cotton crop depends on the plant phenology at the time that readings are recorded by the sensor (ZARCO-TEJADA et al., 2005). Thus, vegetation index can be used to estimate cotton yield variability, mainly in that cases where there is not a yield monitor installed on the cotton picker or to estimate yield in field areas harvested on the past (VELLIDIS et al., 2004). But, vegetation index maps can be trustable in all conditions to estimate cotton yield?

The crop growth rate is highly variable due to the processes that operate on multiple temporal and spatial scales. This variability is governed by the interactions between the soil properties (e.g., texture, nutrient composition) and aspects of landscape related to the movement of water in the soil, and interfering on the vegetation index variability (LI et al., 2001; GUO et al., 2012; MUÑOZ et al., 2014). The yield crop potential is linked to specific soil and weather conditions that occur since the plant's establishment (OLLINGER, 2011). The condition, distribution, structure and the development of the vegetation through the phenological stages can affect the relation between yield and NDVI (DALEZIOS et al., 2001). Koo and Cindy (2015) noted that the yield is impacted by the manner in which daily precipitation is distributed during the crop cycle. According to Jones et al. (2003), the water regime variability can be 
measured by the coefficient of variation $(\mathrm{CV})$ of the precipitation and predict crop yield.

Then, the same statistical CV of the NDVI variability could be used to correlate maps from different crop seasons, and to estimate yield. The objective of this work was to correlate the yield and variability of the NDVI in cotton fields by analyzing the data of Landsat satellite images acquired over nine growing seasons.

\section{MATERIAL AND METHODS}

The data used in this study were obtained from 101 cotton crop fields located in the Cerrado region, West-central Brazil. The fields were located in the southwest region of Goiás State, in the municipality of Chapadão do Céu, and north of Mato Grosso do Sul State, in the municipality of Costa Rica. The corresponding coordinates vary between -18.0 to $-19.1^{\circ}$ latitude and -52.4 to $-53.6^{\circ}$ longitude.

The climate, according to the KöppenGeiger classification, is defined as type Aw (tropical weather with a dry winter season). The annual average rainfall is $2,096 \mathrm{~mm}$ and is distributed between September and April. The annual average temperature is $22.3^{\circ} \mathrm{C}$, with monthly averages ranging from 20.1 to $23.5^{\circ} \mathrm{C}$. The topography is predominantly flat with gentle slopes ranging from 724-898 $\mathrm{m}$ asl (above sea level), generating an average of $807 \mathrm{~m}$ asl.
BAIO, F. H. R. et al

Cotton is typically planted in December and harvest occurs from July to August of the subsequent year (ANSELMO et al., 2015). Thus, the typical agricultural year corresponds to two consecutive years in the Julian calendar. This study analyzed the average yield data of 101 cotton fields from 2004/05 to 2013/14 agricultural years, except for the growing season 2005/06, due to cloud obstruction of the available Landsat images during the relevant acquisition period. Data were collected from 11 cotton fields per year, except in 2010/11/12, which were collected from 12 cotton fields due to the increased data availability, providing 101 datasets from 10,848 ha.

For each cotton field, the average yield was calculated based on the amount of cotton fiber $(\mathrm{kg}$ $\mathrm{ha}^{-1}$ ) obtained from the total harvested per field, which was provided by the cotton mill. Average values of the NDVI were calculated from the orbital Landsat images and the coefficient of variation of the NDVI (CV-NDVI); both values were obtained from the pixels of each imaged field during each crop cycle. The CV-NDVI was calculated by dividing the standard deviation of the NDVI values obtained from the pixels of the images, by its average.

The Landsat images used for this analysis with its acquisition dates are listed in Table 1. Landsat 7 ETM+ images were used after 2012, due to acquisition closure of Landsat 5 , because of its sensor failure in 2003.

Table 1. Landsat images used to calculate the normalized difference vegetation index (NDVI) and its coefficient of variation (CV-NDVI) from cotton fields.

\begin{tabular}{lcc}
\hline Year & Date & Satellite* \\
\hline 2005 & $04 / 07 / 2005$ & \\
2007 & $03 / 27 / 2007$ & \\
2008 & $03 / 30 / 2008$ & Landsat 5 \\
2009 & $04 / 17 / 2009$ & TM \\
2010 & $04 / 20 / 2010$ & \\
2011 & $04 / 07 / 2011$ & Landsat 7 \\
\hline 2012 & $04 / 02 / 2012$ & ETM+ \\
2013 & $04 / 20 / 2013$ & \\
2014 & $04 / 07 / 2014$ & \\
\hline
\end{tabular}

*Path/Row: 224/073.

The moments of image acquisition used for analysis were determined by the phenological stage of the cotton crop; between 80-120 days after emergence of the seedlings. This period coincides with the development of the most viable fruit, which is a critical growth phase to determine yield. The physiological plant activity is intense in this phase, mainly due to the formation of seeds and fiber (ECHER et al., 2014). Zhao et al. (2007) mentioned that this period has the highest correlation between NDVI (obtained by orbital images) and cotton yield. Iqbal et al. (2013) concluded that a single multispectral image during the fruiting phenological 
phase is sufficient to estimate the spatial variability of cotton fiber yield.

The selected multispectral images were acquired from the USGS EarthExplorer (United States Geological Survey). The composition of the bands, their projection to the southern hemisphere, georeferencing and NDVI calculations were performed by ArcMap 10.3 software (ESRI, Redlands, CA, USA). After the radiometric calibration (ALLEN et al., 2002), the images were georeferenced based on the field boundaries that were obtained by walking around each field perimeter with a GNSS JD Starfire 3000 model, with JD differential correction SF 2 (John Deere, Moline, IL, USA).

A buffer zone was established by displacing the field perimeter $30 \mathrm{~m}$ toward its interior, to ensure that the NDVI values of each image pixel were coming from the reflectance of the plant canopies inside the target field. This distance was based on the pixel image size required to eliminate the effects of the surrounding areas, such as roads or portions of neighboring fields in the analysis.

The data were analyzed by descriptive statistics and Pearson's linear correlation. The t-test with n-2 degrees of freedom was used to verify the significance of this correlation. The correlation between CV-NDVI and the average cotton yield from each field were adjusted according to the segmented regression Equation [1]:

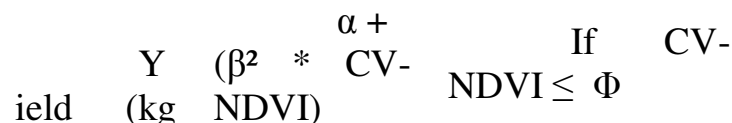

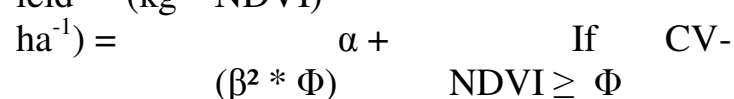

Where $\boldsymbol{\alpha}$ represents the initial yield value $\left(\mathrm{kg} \mathrm{ha}{ }^{-1}\right), \boldsymbol{\beta}$ is the rate of yield decrease $\left(\mathrm{kg} \mathrm{ha}^{-1}\right)$, $\mathrm{CV}-\mathrm{NDVI}$ represents the value of the $\mathrm{CV}$ obtained in the field, and $\mathbf{\Phi}$ corresponds to the value at which the model reaches a plateau $\left(\mathrm{kg} \mathrm{ha}^{-1}\right)$.

The segmented linear regression was adjusted assuming yield a dependent variable and CV-NDVI an independent variable. The purpose of this adjustment was to understand the relationship between NDVI variability and cotton yield decrease, and the value of CV-NDVI at which the variability effect was significant. The methodology used to adjust the segmented regression model was proposed by Ryan and Porth (2007). Their piecewise model provides a type of regression that allows multiple linear models to be fitted to the data at different values of the independent variable.
Peixoto et al. (2011) and Sousa et al. (2015) obtained satisfactory results using the piecewise regression model to adjust the $\mathrm{CV}$ in relation to the number of in vitro test repetitions. The software used to perform the statistical analysis in the current study was INFOSTAT version 2015e (Universidad Nacional de Cordoba, Cordoba, Argentina).

\section{RESULTS AND DISCUSSION}

From 101 cotton fields analyzed over nine growing seasons, the average fiber yield was 1,281 $\mathrm{kg} \mathrm{ha}^{-1}$, ranging from 393 up to $2,030 \mathrm{~kg} \mathrm{ha}^{-1}$, presenting a significant yield variability. Approximately $25 \%$ of the fields presented yields below $974 \mathrm{~kg} \mathrm{ha}^{-1}$, while another $25 \%$ presented yields greater than $1,600 \mathrm{~kg} \mathrm{ha}^{-1}$. Several factors contributed to the cotton yield variability. Lamas and Ferreira (2011) mentioned essential factors affecting cotton yield in the same crop region included, the technology adopted, and investment performed by the farmer, availability of new varieties and biotechnologies, and crop rotation. Variables related to weather conditions throughout the crop cycle also influence the definition of yield.

The average NDVI from all 101 cotton fields was 0.58 and ranged from 0.34 to 0.76 . ZarcoTejada et al. (2005) obtained a similar average NDVI value from hyperspectral images acquired in a similar phenological period. The proposed variability indicator, CV-NDVI, varied from 2.5 to $48.7 \%$, with an average value of $13.5 \%$. The CVNDVI value depends on the type of response variable analyzed. For example, values higher than $16 \%$ for soybean yields and $22 \%$ for maize yield can be considered high (CARVALHO et al., 2003).

NDVI values had a significant correlation by t-test with the fiber yield, with a coefficient of correlation (r) of 0.37 (Figure 1A). Zhao et al. (2007) mentioned correlation values between NDVI and cotton yield ranging from 0.54 to 0.76 , based on a two-year evaluation. Dalezios et al. (2001) analyzed orbital images of various locations in a three-year period to estimate cotton yield on a regional scale, and they obtained a correlation of 0.62 between NDVI and yield. The authors concluded that the correlation degree between these two factors depended on the field and the year, although, the variability over the absolute average values of NDVI reflected the variability in regional yield during the three growing seasons (DALEZIOS et al., 2001). 

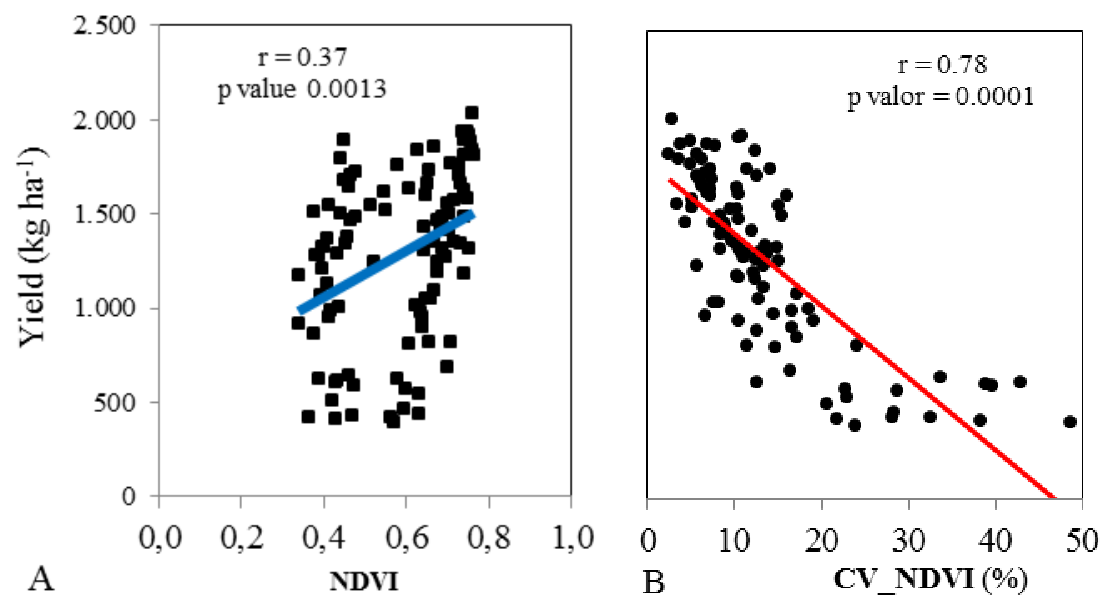

Figure 1. Linear Pearson correlation between average cotton yield from each field and normalized difference vegetation index (NDVI) (A) and coefficient of variation of NDVI (CV-NDVI) (B).

The correlation between yield variability and the vegetation index improved from 0.37 to 0.78 when CV-NDVI and cotton yield was considered (Figure 1B). Interannual analyzes of NDVI data might be imprecise due to the interference of several factors, emphasizing the image acquisition date and its association with the crop phenological phase (VENTERIS et al., 2015).

Gutierrez et al. (2012) demonstrated that the use of vegetation indexes, especially NDVI, to estimate yield might have restrictions in some situations, especially when there is an asymmetry between the vegetative and reproductive growth phases. The cotton crop has a $\mathrm{C} 3$ photosynthetic system, whose biomass production has no direct correlation with yield, in contrast to what occurs with $\mathrm{C} 4$ plants, such as grasses (THENKABALL et al., 2000).

Figure 2 presents the NDVI response over three consecutive years using a representative field as an example. In 2009, the cotton yield harvested was $1,664 \mathrm{~kg} \mathrm{ha}^{-1}$, or $25 \%$ higher than the general average. The average CV-NDVI was $7.3 \%$, corresponding to $46 \%$ less than the average CVNDVI. In 2010, cotton yield was $473 \mathrm{~kg} \mathrm{ha}^{-1,}$ and the average CV-NDVI for that field was $26.9 \%$, an increment associated with excessive rain in the crop establishment. There were severe restrictions on the cotton growth in parts of the field with excessive soil moisture. In that year, the cotton crop presented a higher spatial variability of the NDVI and lower harvest yield, compared to the years 2009 and 2011.
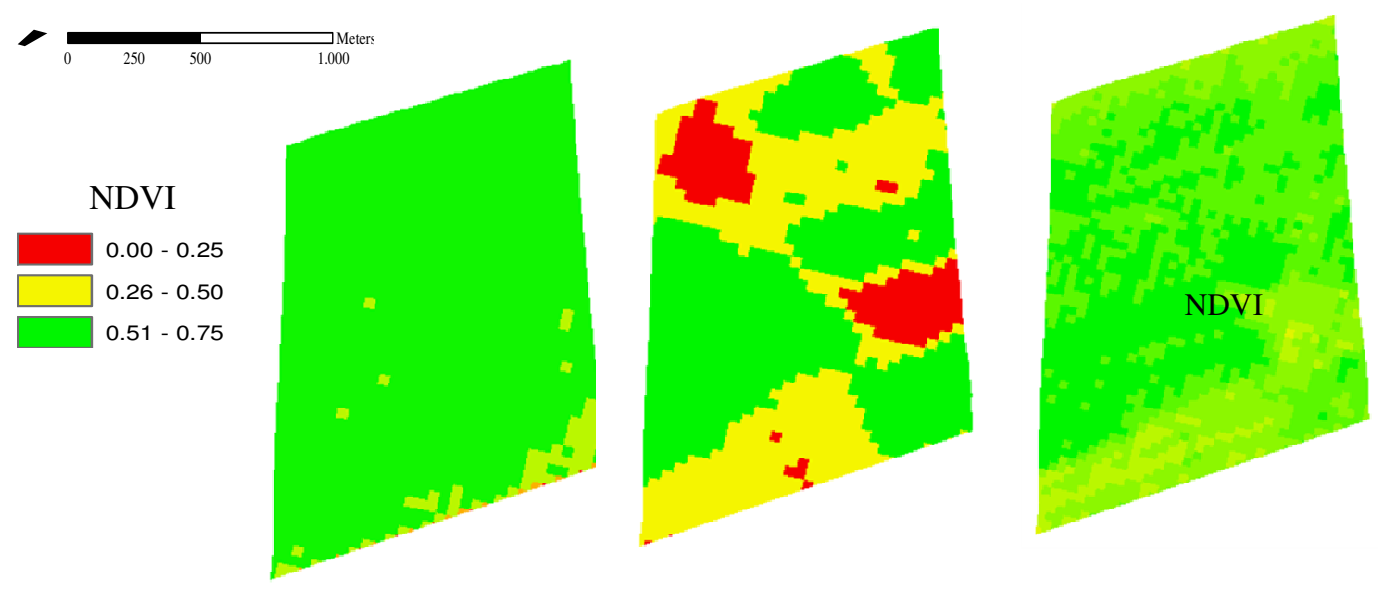

\begin{tabular}{llll}
\hline & 2009 & 2010 & 2011 \\
\hline Yield $\left(\mathrm{kg} \mathrm{ha}^{-1}\right)$ & 1,664 & 473 & 1,304 \\
NDVI & 0.61 & 0.47 & 0.50 \\
CV-NDVI & 7.3 & 26.9 & 13.7 \\
\hline
\end{tabular}

Figure 2. Yield of the cotton fiber, normalized difference vegetation index (NDVI) and coefficient of variation of the NDVI (CV-NDVI) in three consecutive years, Data were based on a representative field, for illustration purposes. 
The CV-NDVI presented significant correlation by t-test with the average cotton field yield. However, the relationship was negative, with $r$ of -0.78 (Fig. 2B). The CV, as a relative dispersion measurement, can be associated with the spatial variability of the cotton plant growth. Zarco-Tejada et al. (2005) demonstrated the heterogeneity of vegetation indexes during the crop cycle and the corresponding spatial variability over the yield. Iqbal et al. (2013) mentioned that differences in physical properties of the field soil influenced growth and NDVI values of the crop, resulting in variability in cotton yield. Li et al. (2001) reported that the nitrate and water soil contents before planting might be important factors influencing growth variability and fertilization response. According to Mallarino et al. (1999), the variables associated with soil water retention (primarily texture) and nutrient availability are the primary factors responsible for spatial variability of the cotton yield. Leon et al. (2003) mentioned that nutrient availability and aspects of the topography were the main factors associated with growth variability and yield within cotton fields.

The yield from 101 cotton fields was statistically modeled in function of CV-NDVI and is presented in Figure 3. The fields that obtained low CV-NDVI, indicating high uniformity on the plant growth, resulted in the highest cotton yield.

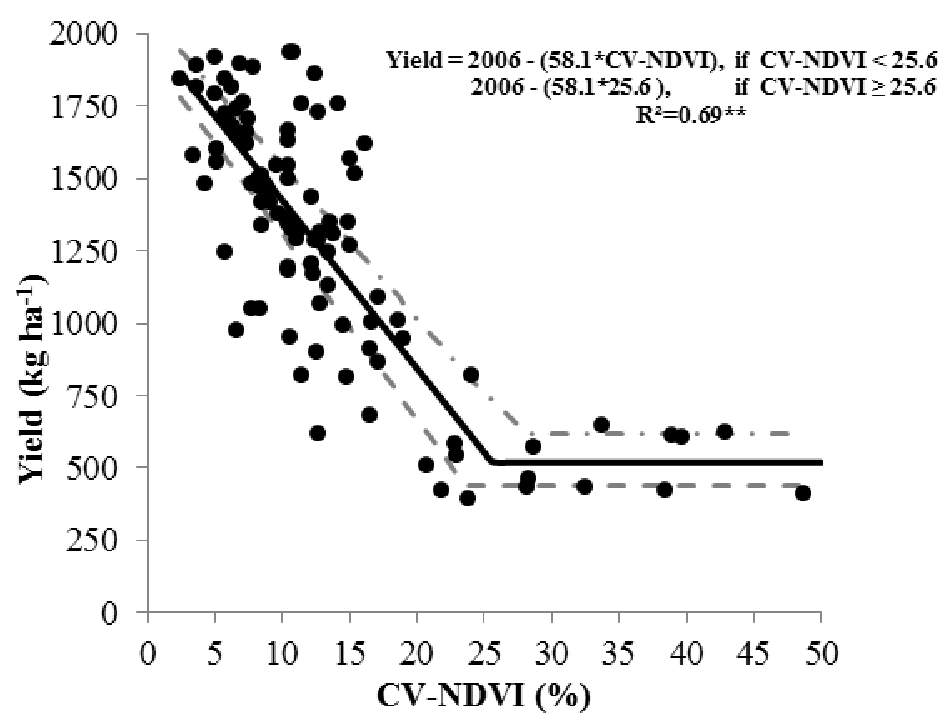

Figure 3. Relationship between cotton fiber yield as a function of the coefficient of variation of the normalized difference vegetation index (NDVI), CV-NDVI, obtained from Landsat images during the crop cycle in nine growing seasons.

Continuous line: the adjusted linear model with plateau; dashed line: confidence interval of $95 \%$.

The cotton yield decreased at a constant rate with increments in the CV-NDVI, up to $25.6 \%$. Above $25.6 \%$, the yield remained stable even increasing the variability. Each percentage point increment in CV-NDVI represented $-58.1 \mathrm{~kg} \mathrm{ha}^{-1}$ of cotton fiber. If the pound (lb) weight unit is applied, which is the standard unit used in the international marketing of cotton, the decrease represents $128 \mathrm{lb}$. In December 2015, the New York Stock Exchange listed cotton at 0.63 USD $l^{-1}$ (TRADING
CHARTS, 2015). Thus, the higher the cotton field variability, the higher the cotton revenue impact.

When the CV-NDVI index increased, the cotton yield decreased (Figure 4). At the regression point where the relative yield was $63 \%$ (average yield of all 101 field cases, or $1,281 \mathrm{~kg} \mathrm{ha}^{-1}$ ), the CV-NDVI was $12.8 \%$. When this index decreased to $6.9 \%$, the relative cotton yield increased to $80 \%$ or $1,624 \mathrm{~kg} \mathrm{ha}^{-1}$. 


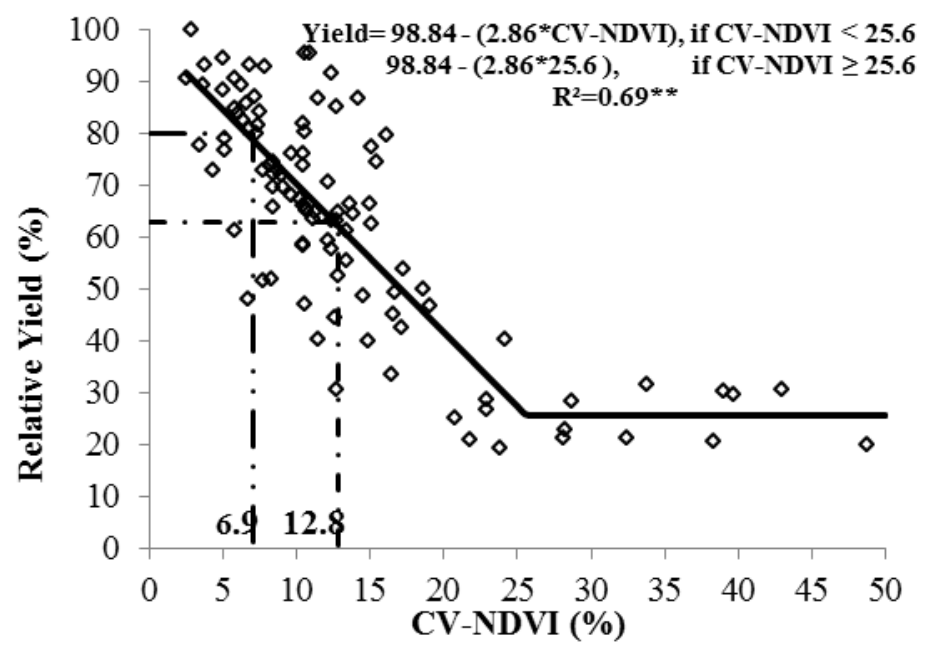

Figure 4. Yield of cotton as a function of the coefficient of variation of the normalized difference vegetation index (NDVI), CV-NDVI, obtained from Landsat images during the crop cycle in nine growing seasons.

At CV values above $25.6 \%$, corresponding to the plateau of the model, the estimated yield was $518 \mathrm{~kg} \mathrm{ha}^{-1}$. This value is $60 \%$ below the overall average yield and represents approximately $25 \%$ of the maximum yield. Fields with a CV-NDVI above $25 \%$ are associated with a critical crop condition during development, such as excessive rainfall on the crop establishment (as verified), the attack of pests, such as Helicoverpa zea, Scaptocoris castanea and Anthomonas grandis, or occurrence of frosts in that year (TOMQUELSKI, 2013).

The heterogeneity in cotton growth leads to difficulties over its management between fields. Practices such as irrigation and application of fertilizers and growth regulator may compromise crop management efficiency in fields with high variability, resulting in an inadequate input rate application for the local demand. Wanjura et al. (2003) mentioned that the spatial uniformity of the crop as it is established is fundamental to achieve high cotton yields.

The effect of factors that influence the spatial and temporal yield variability is usually associated with the growth parameters of the crop. Consequently, monitoring the crop growth can help site-specific management to improve yields or efficiency of input uses (MACHADO et al., 2002). Precision agriculture is an important strategy to implement before and/or during the crop cycle, by correction of the soil in specific locations or by application of a variable rate of seed, nitrogen fertilizer, growth regulator or defoliant.

Booker et al. (2015) demonstrated that soil and growth parameters required by cotton crops grown in different climatic conditions could be modeled in temporal and spatial resolution to be applied in management practices. Another option for managing crop variability, in corn and cotton, for example, is the application of variable-rate nitrogen to suit the crop needs across different locations (MAHLEIN et al., 2012; HOLLAND; SCHEPERS, 2013; BRAGAGNOLO et al., 2013; ZHOU; YIN, 2014).

\section{CONCLUSIONS}

The increment in the NDVI variability, indicated by the $\mathrm{CV}$ of the vegetation index and calculated from a multispectral image, reflected a decrease in average cotton yield.

The CV-NDVI index provided a more accurate characterization of crop yield changes between seasons than the absolute NDVI average value.

The decrease in average cotton yield, related to the increment of the $\mathrm{CV}$, was constant, providing the vegetation index remained below $25.6 \%$.

\section{ACKNOWLEDGMENTS}

Special thanks to the Foundation to Support the Development of Education, Science and Technology of the State of Mato Grosso do Sul (FUNDECT) and to Wink Farms Group for supporting this work. 
RESUMO: Desde a disponibilização das imagens de satélites, tem-se gerado grande número de estudos regionais e globais para caracterizar a vegetação. Esses estudos têm relacionado parâmetros de crescimento, nutricionais, fisiológicos, hídricos e produtividade das culturas agrícolas ou vegetação nativa. O NDVI (Normalized Difference Vegetation Index) é associado com parâmetros de crescimento e produtividade do algodoeiro com leituras em vários momentos do ciclo. O objetivo desse trabalho foi relacionar a variabilidade do NDVI em campos de produção de algodão e a produtividade pelo uso de imagens do satélite Landsat ao longo de nove safras. O estudo foi desenvolvido com análise de 101 campos de produção localizados na região central do Brasil. Foi utilizada uma imagem durante o ciclo da cultura e a produtividade média obtida. A produtividade de fibra variou de 393 a $2.030 \mathrm{~kg} \mathrm{ha}^{-1}$ e a correlação com NDVI foi de 0,37 . O coeficiente de variação teve correlação negativa, com queda na produtividade em $-58,1 \mathrm{~kg} \mathrm{ha}^{-1}$ ao aumentar um ponto percentual. O coeficiente de variação explicou melhor a variabilidade da produtividade dos talhões que o NDVI médio.

PALAVRA-CHAVE: Coeficiente de variação. imagem orbital. Índice de Vegetação.

\section{REFERENCES}

ALLEN, R. G.; TASUMI, M.; TREZZA, R.; WATERS, R.; BASTIAANSSEN, W. G. M. Surface Energy Balance Algorithm for Land (SEBAL) - Advanced Training and User's Manual. Kimberly, ID, USA: University of Idaho, 2002.

ANSElMO, J. L., ANDRADE, B. G. M., DA SILVA, D. C., VIANA, D. R., DE ÁVILA, J., DA SILVA, T. R., MUDINUTTI, L., TEIXEIRA, D. S., MERLOTI, L. F. Ensaio comparativo de variedade de algodão em época e espaçamento distintos, Chapadão do Sul-MS. Fundação Chapadão, Chapadão do Sul, v. 5, p. 18-23, 2015.

BOOKER, J. D., LASCANO, R. J., MOLLING, C. C., ZARTMAN, R. E., ACOSTA-MARTÍNEZ, V. Temporal and spatial simulation of production-scale irrigated cotton systems. Precision Agriculture, v. 16, p. 630-653, 2015.

BRAGAGNOLO, J., AMADO, T. J. C., NICOLOSO, R. D. S., JASPER, J., KUNZ, J., TEIXEIRA, T. D. G. Optical crop sensor for variable-rate nitrogen fertilization in corn: plant nutrition and dry matter production. Revista Brasileira de Ciência do Solo, Viçosa, v. 37, p. 1288-1298, 2013.

CARVAlHO, C. G. P. D., ARIAS, C. A. A., TOLEDO, J. F. F. D., ALMEIDA, L. A. D., KIIHL, R. A. D. S., OLIVEIRA, M. F. D., HIROMOTO, D. M.; \& TAKEDA, C. Proposta de classificação dos coeficientes de variação em relação à produtividade e altura da planta de soja. Pesquisa Agropecuária Brasileira, Brasília, v. 38, p. 187-193, 2003.

CLAVERIE, M., VERMOTE, E. F., FRANCH, B., MASEK, J. G. Evaluation of the Landsat-5 TM and Landsat-7 ETM+ surface reflectance products. Remote Sensing of Environment, v. 169, p. 390-403, 2015.

DALEZIOS, N. R., DOMENIKIOTIS, C., LOUKAS, A., TZORTZIOS, S. T., KALAITZIDIS, C. Cotton yield estimation based on NOAA/AVHRR produced NDVI. Physics and Chemistry of the Earth (B), v. 26, p. 247-251, 2001.

ECHER, F. R. O algodoeiro e os estresses abióticos. In F. ECHER (Ed.). O algodoeiro e os estresses abióticos: temperatura, luz, água e nutrientes. Cuiabá: Instituto Mato-Grossense do Algodão, 2014. p. 9-13.

GUO, W., MAAS, S. J., BRONSON, K. F. Relationship between cotton yield and soil electrical conductivity, topography, and Landsat imagery. Precision Agriculture, v. 13, p. 678-692, 2012.

GUTIERREZ, M., NORTON, R., THORP, K. R., WANG, G. Association of spectral reflectance indices with plant growth and lint yield in upland cotton. Crop Science, v. 52, p. 849-857, 2012. 
HOLLAND, K. H., SCHEPERS, J. S. Use of a virtual-reference concept to interpret active crop canopy sensor data. Precision Agriculture, v. 14, p. 71-85, 2013.

IQBAL, J., READ, J. J., WHISLER, F. D. Using remote sensing and soil physical properties for predicting the spatial distribution of cotton lint yield. Turkish Journal of Field Crops, v. 18, p. 158-165, 2013.

JONES, J.W., HOOGENBOOM, G., PORTER, C. H., BOOTE, K.J., BATCHELOR, W. D., HUNT, L. A., WILKENS, P. W., SINGH, U., GIJSMAN, A. J., \& RITCHIE, J. T. The DSSAT cropping system model. European Journal of Agronomy, v. 18, p. 235-265, 2003.

KOO, J., CINDY, C. Effects of rainfall variability on maize yields. In K. Sebastian (Ed.), Atlas of African agriculture research and development: revealing agriculture's place in Africa (pp. 44-45). Washington, USA: International Food Policy Research Institute, 2015.

LAMAS, F. M., FERREIRA, A. C. B. Reguladores de crescimento, desfolhantes e maturadores. In E. C. Freire (Ed.), Algodão no Cerrado do Brasil (2 ${ }^{\text {nd }}$ E. pp. 777-790). Brasilia, Brazil: ABRAPA, 2011.

LEON, C. T., SHAW, D. R., COX, M. S., ABSHIRE, M. J., WARD, B., WARDLAW III, M. C., WATSON, C. Utility of remote sensing in predicting crop and soil characteristics. Precision Agriculture, v. 4, p. 359-384, 2003.

LI, H., LASCANO, R. J., BARNES, E. M., BOOKER, J., WILSON, L. T., BRONSON, K. F., SEGARRA, E. Multispectral reflectance of cotton related to plant growth, soil water and texture, and site elevation. Agronomy Journal, Madison, v. 93, p. 1327-1337, 2001.

MACHADO, S., BYNUM, E. D. JR., ARCHER, T. L, LASCANO, R. J., WILSON, L. T., BORDOVSKY, J., SEGARRA, E., BRONSON, K., NESMITH, D. M., XU, W. Spatial and temporal variability of corn growth and grain yield. Crop Science, v. 42, p. 1564-1576, 2002.

MAHLEIN, A. K., OERKE, E. C., STEINER, U., DEHNE, H. W. Recent advances in sensing plant diseases for precision crop protection. European Journal of Plant Pathology, v. 133, p. 197-209, 2012.

MALLARINO, A. P., OYARZABAL, E. S., HINZ, F. N. Interpreting within-field relationships between crop yield and plant variables using factor analysis. Precision Agriculture, v. 1, p. 15-25, 1999.

MUÑOZ, J. D., STEIBEL, J. P., SNAPP, S., KRAVCHENKO, A. N. Cover crop effect on corn growth and yield as influenced by topography. Agriculture, Ecosystems \& Environment, v. 189, p. 229-239, 2014.

OLLINGER, S. V. Sources of variability in canopy reflectance and the convergent properties of plants. New Phytologist, v. 189, p. 375-394, 2011.

PEIXOTO, A. P. B., FARIA, G. A., MORAIS, A. R. Modelos de regressão com platô na estimativa do tamanho de parcelas em experimento de conservação in vitro de maracujazeiro. Ciência Rural, Santa Maria, v. 41, p. 1907-1913, 2011.

RYAN, S. E., PORTH, L. S. A tutorial on the piecewise regression approach applied to bedload transport data. General Technical Report RMRS-GTR-189. Fort Collins, USA: Rocky Mountain Research Station, Forest Service, U.S. Department of Agriculture, 2007. 41p.

SOUSA, R. P., PAUlO, S. L., SILVA, J. P., DA SILVA, J., DE OLIVEIRA, V. R., \& OLIVEIRA, A. M. D. P. Tamanho ótimo de parcela para avaliação do rendimento de grãos do girassol. Revista Brasileira de

Engenharia Agrícola e Ambiental, Campina Grande, v. p. 19, 21-26, 2015. 
THENKABAIL, P. S., SMITH, R. B., DE PAUW, E. Hyperspectral vegetation indices and their relationships with agricultural crop characteristics. Remote Sensing of Environment, v. 71, p. 158-182, 2000.

TOMQUELSKI, G. V. Pragas em algodoeiro na região dos Chapadões. Fundação Chapadão, Chapadão do Sul, v. 5, p. 7-32, 2013.

TRADING CHARTS. Commodity futures price quotes for cotton. Resource Document. Trading Charts. http://futures.tradingcharts.com Accessed 01 December 2015.

VELLIDIS, G., TUCKER, M. A., PERRY, C. D., THOMAS, D. L., WELLS, N., KVIEN, C. K. Predicting cotton lint yield maps from aerial photographs. Precision Agriculture, v. 5, p. 547-564, 2004.

https://doi.org/10.1007/s11119-004-6342-5

VENTERIS, E. R., TAGESTAD, J. D., DOWNS, J. L., MURRAY, C. J. Detection of anomalous crop condition and soil variability mapping using a 26 year Landsat record and the Palmer crop moisture index.

International Journal of Applied Earth Observations and Geoinformation, v. 39, p. 160-170, 2015.

WALSH, O. S., KLATT, A. R., SOLIE, J. B., GODSEY, C. B., RAUN, W. R. Use of soil moisture data for refined GreenSeeker sensor based nitrogen recommendations in winter wheat (Triticum aestivum L.). Precision Agriculture, v. 14, p. 343-356, 2012.

WANJURA, D. F., UPCHURCH, D. R., MAAS, S. J., WINSLOW, J. C. Spectral detection of emergence in corn and cotton. Precision Agriculture, v. 4, p. 385-399, 2003.

WIENS, J. A., STRALBERG, D., JONGSOMJIT, D., HOWELL, C. A., SNYDER, M. A. Niches, models, and climate change: assessing the assumptions and uncertainties. Proceedings of the National Academy of

Sciences USA, v. 106, p. 19729-19736, 2009. https://doi.org/10.1073/pnas.0901639106

YANG, C., \& EVERITT, J. H. Using spectral distance, spectral angle and plant abundance derived from hyperspectral imagery to characterize crop yield variation. Precision Agriculture, v. 13, p. 62-75, 2012.

YANG, C., ODVODY, G. N., FERNANDEZ, C. J., LANDIVAR, J. A., MINZENMAYER, R. R., NICHOLS, R. L. Evaluating unsupervised and supervised image classification methods for mapping cotton root rot.

Precision Agriculture, v. 16, p. 201-215, 2015.

ZARCO-TEJADA, P. J., USTIN, S. L., WHITING, M. L. Temporal and spatial relationships between withinfield yield variability in cotton and high-spatial hyperspectral remote sensing imagery. Agronomy Journal, v. 97, p. 641-653, 2005.

ZHAO, D., REDDY, K. R., KAKANI, V. G., READ, J. J., KOTI, S. Canopy reflectance in cotton for growth assessment and lint yield prediction. European Journal of Agronomy, v. 26, p. 335-344, 2007.

ZHENG, G., MOSKAL, L. M. Retrieving leaf area index (LAI) using remote sensing: theories, methods and sensors. Sensors, v. 9, p. 2719-2745, 2009.

ZHOU, G., YIN, X. Relationship of cotton nitrogen and yield with normalized difference vegetation index and plant height. Nutrient Cycling in Agroecosystems, v. 100, p. 147-160, 2014. 